\title{
Effect of Integrated Nutrient Management on Growth and Yield Attributes in Potato (Solanum tuberosum L.)
}

\author{
A.S. Shubha*, V. Srinivasa, A. Shanwaz, R.B. Anusha and M.B. Sharavathi \\ Department of vegetable science, College of Horticulture, Mudigere, University of \\ Agricultural and Horticultural sciences, Shivamogga, Karnatka, India \\ *Corresponding author
}

\section{A B S T R A C T}

Keywords

Potato, Soil available nutrients, Leaf tissue $\mathrm{N}, \mathrm{P}$ and $\mathrm{K}$

\section{Article Info}

Accepted:

06 August 2018

Available Online:

10 September 2018
The present study was conducted to investigate the "Effect of integrated nutrient management on growth, yield and quality of potato". Experiment was laid out in the randomized block design with 14 treatments. The results revealed that application of Azotobacter $+\mathrm{PSB}+\mathrm{KSB}+\mathrm{MgSO}_{4}+$ micro nutrient mixture +75 $\%$ RDF $\left(\mathrm{T}_{13}\right)$ recorded significantly maximum LAI (5.25), fresh weight of leaves $(45.41 \mathrm{~g})$, stem $(74.67 \mathrm{~g})$, tuber $(301.67 \mathrm{~g})$, dry weight of leaves $(9.39 \mathrm{~g})$, stem $(17.90 \mathrm{~g})$, tuber $(55 \mathrm{~g})$. Quality attributes like tuber length $(8.79 \mathrm{~cm})$ and tuber circumference $(15 \mathrm{~cm})$ were also found maximum in the same treatment compared to control.

\section{Introduction}

Potato (Solanum tuberosum L) native to tropical South America and one of the most efficient food crop which produces more dry matter, dietary fibre, quality protein, minerals, vitamins and richest source of energy. The area and production of potato in the country is estimated around 20.85 lakh hectares and 480.96 lakh million tonnes, respectively with the productivity of 23.07 tonnes per hectare (Anon., 2015). In order of importance for food production in comparison to other major food crops on the fresh weight basis, potato ranks $6^{\text {th }}$ in developing countries, $4^{\text {th }}$ in developed countries and $3^{\text {rd }}$ in India (Khurana and Naik, 2003). The protein in potato is of good quality with regard to essential amino acids in human nutrition. It also has the substantial amount of vitamins, minerals and traces of other nutrients. With all these characters, potato undoubtedly a very important crop for countries with the high human population density like India where adequate protein and calories can be supplied cheaply for the nutritional needs calling it as "Poor man's crop".

Chemical fertilizers are not only in limited supply but also expensive in developing countries like India. The price of chemical fertilizer is increasing day by day, moreover, the continuous use of these fertilizers adversely affects the soil health, which is a major concerned for farmers. Integrated supply of nutrients through organic, inorganic 
and bio fertilizers is the need of the hour for sustainable productivity and to maintain better soil health (Jagadeesh et al., 1994). To increase the production and quality of potato, judicious combination of organic sources of nutrients along with inorganic and biofertilizers (Azotobactor and phosphobacteria) receive the good response (Nag, 2006). Phosphate solubilizing Bacteria (PSB) are capable of hydrolyzing organic and inorganic phosphorus from insoluble compounds and PSB produce phosphatase like phytase that hydrolyse organic forms of phosphate compounds efficiently. Biofertilizers are living organisms used in the fertilization of soil and are useful in supplementing the usual application of chemical fertilizers and help in enriching the soil.

Modern nutrient management strategy has shifted its focus towards the concept of sustainability and eco-friendliness. Intensive use of only chemical fertilizers to achieve high production has created various problems. Continuous application of heavy doses of chemical fertilizers without organic manures or bio fertilizers has led to a deterioration of soil health in terms of physical and chemical properties of soil, declining of soil microbial activities, reduction in soil humus, increased pollution of soil, water and air.

Hence, considering the economy, environment friendliness and maintain better soil health, it is imperative that plant nutrients are to be used effectively by adopting the integrated nutrient management practices. The basic principle behind this concept is to supply both the chemical fertilizers and organic manures for a sustainable crop production in most efficient manner, although the modern technique of intensive crop production needs the use of chemical fertilizers. Keeping this in mind the experiment was undertaken to find the effect of INM on growth, yield and quality of potato.

\section{Materials and Methods}

The experiment was conducted at department of vegetable science in College of Horticulture, Mudigere. The experiment was conducted in RCBD design with 14 set of treatments replicated thrice. The experimental details is as follows: $\mathrm{T}_{1}-$ control (RDF:125:100:125 Kg/ha + FYM 25 t/ha), $\mathrm{T}_{2}$ $-75 \% \mathrm{RDF}+$ Vermicompost (2.5 t/ha), $\mathrm{T}_{3}-75$ $\%$ RDF + Vermicompost + Azotobacter, $\mathrm{T}_{4}$ $100 \% \mathrm{RDF}+$ Azotobacter, $\mathrm{T}_{5}-75 \% \mathrm{~N}+\mathrm{RD}$ of $\mathrm{P}$ and $\mathrm{K}+$ Azotobacter $\mathrm{T}_{6}-100 \% \mathrm{RDF}$ $+\mathrm{PSB}, \mathrm{T}_{7}-75 \% \mathrm{P}+\mathrm{RD}$ of $\mathrm{N}$ and $\mathrm{K}+\mathrm{PSB}, \mathrm{T}_{8}$ $-100 \% \mathrm{RDF}+\mathrm{KSB}, \mathrm{T}_{9}-75 \% \mathrm{~K}+\mathrm{RD}$ of $\mathrm{N}$ and $\mathrm{P}+\mathrm{KSB}, \mathrm{T}_{10}-50 \% \mathrm{RDF}+\mathrm{VC}+$ Azotobacter $+\mathrm{PSB}+\mathrm{KSB}, \mathrm{T}_{11}-\mathrm{T}_{10}+\mathrm{MgSO}_{4}$ + Micronutrient mixture, $\mathrm{T}_{12}-75 \% \mathrm{RDF}+$ Azotobacter $+\mathrm{PSB}+\mathrm{KSB}, \mathrm{T}_{13}-\mathrm{T}_{12}+\mathrm{MgSO}_{4}$ + Micronutrient mixture, $\mathrm{T}_{14}-\mathrm{RDF}+\mathrm{MgSO}_{4}$ + Micronutrient mixture. Observations on growth and yield parameters were recorded and subjected to statistical analysis. The procedure for recording the observations are mentioned below.

The leaf area index at various stages was calculated by using formula suggested by Sestak et al., (1971)

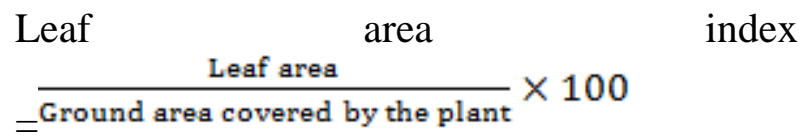

\section{Fresh and dry weight of leaves (g)}

Fresh weight of leaves of randomly selected five plants from each plot was recorded at the time of 30 DAS, 60 DAS and haulm cutting. The portion of the leaves above ground level was separated from the plants with the help of sickle and it was weighed to obtain the fresh weight of leaves per plant and is expressed in grams per plant. After recording the fresh weight of leaves per plant, leaves of the tagged plants were dried in an oven at $800{ }^{\circ} \mathrm{C}$ 
for 72 hours till constant weight was achieved and their average dry weight was expressed in grams per plant.

\section{Fresh and dry weight of stem (g)}

The fresh weight of stem was taken from each of tagged plants in each replication and the average fresh weight of stem was expressed in grams per plant. After recording the fresh weight of stem per plant, the stem of the tagged plants was collected at three intervals 30 DAS, 60 DAS and 90 DAS and dried in the oven at $800{ }^{\circ} \mathrm{C}$ for 72 hours till constant weight was achieved and their average dry weight was expressed in grams per plant.

\section{Fresh and dry weight of tuber (g)}

This observation was recorded from tagged and uprooted five plants at 60 DAS and at the time of harvesting with the help of physical balance and averaged and it is expressed in grams. After recording the fresh weight of tubers per plant, the tubers were sliced into chips and left for natural sun drying for five days. The samples were finally kept in the hot air oven for 12 hours at $600{ }^{\circ} \mathrm{C}$ till constant weight was achieved and weighed on the digital balance. The data of five individual plants were then averaged and expressed in grams.

\section{Total fresh and dry weight of tuber (g)}

Total fresh weight of the tuber was calculated by summing up all the fresh weight of tuber which was taken at different intervals and then it was averaged and their mean value is expressed in grams per plant.

Total dry weight of the tuber was calculated by summing up all the dry weight of tuber which was taken at different intervals and then it was averaged and their mean value is expressed in grams per plant.

\section{Tuber length and circumference $(\mathrm{cm})$}

Tuber length and circumference was recorded from the tagged five plants and expressed in centimeters.

\section{Tuber shape, size and depth of eyes}

The shape of tubers was recorded on the basis of visual observation for all the treatments. Where, oval, round and oblong were observed. The tuber size of all the varieties recorded by weighing and recording the readings by big, medium and small size. The depth of tuber eyes in each treatment was recorded as shallow, fleet (medium deep) and deep by visual observation during the storage period.

\section{Results and Discussion}

Leaf area index were significantly varied among the various treatments (Fig. 1). LAI (5.25) was found with application of Azotobacter + PSB + KSB $+75 \% \mathrm{RDF}+$ $\mathrm{MgSO}_{4}+$ Micronutrient mixture $\left(\mathrm{T}_{13}\right)$ compared to RDF $\left(\mathrm{T}_{1}\right)$. Leaf area and leaf area index decides the efficiency of photosynthetic activity and contributes towards better growth and yield of the crop. Chopra et al., (2006) stated that there was increase in leaf area index with increasing nitrogen levels $(0,125$, 187.5 and $250 \mathrm{~kg} / \mathrm{ha}$ ) in potato cv. Kufri Jawahar.

Fresh weight accumulation was significantly influenced by integrated nutrient management practices in potato (Table 1 and plate 1). The highest fresh weight of leaves (45.41 g), stem $(74.67 \mathrm{~g})$, tubers $(301.67 \mathrm{~g})$ were found in the plants supplied with Azotobacter + PSB + $\mathrm{KSB}+75 \% \mathrm{RDF}+\mathrm{MgSO}_{4}+$ Micronutrient mixture $\left(T_{13}\right)$. The fresh weight of leaves, stem and tubers were on par with $\mathrm{T}_{11}, \mathrm{~T}_{14}$ and $\mathrm{T}_{12}$. The maximum dry weight of leaves, stem and tuber $(9.39 \mathrm{~g}, 17.90 \mathrm{~g}$ and $55 \mathrm{~g}$, respectively) were found in the treatment with 
the combination of Azotobacter $+\mathrm{PSB}+\mathrm{KSB}$ $+75 \% \mathrm{RDF}+\mathrm{MgSO}_{4}+$ Micronutrient mixture $\left(T_{13}\right)$ which was on par with $T_{11}, T_{14}$ and $\mathrm{T}_{12}$ (Table 1). Similarly, the total fresh and dry weight of the tubers (426.67 $\mathrm{g}$ and $96.67 \mathrm{~g}$, respectively) were also recorded maximum with the plants receiving Azotobacter + PSB + KSB + $75 \% \mathrm{RDF}+$ $\mathrm{MgSO}_{4}+$ Micronutrient mixture $\left(\mathrm{T}_{13}\right)$ which were on par with $T_{11}, T_{14}$ and $T_{12}$. The results were in conformity with the findings of Yadu (2011) who stated that growth parameters like fresh weight of shoots per plant, dry weight of shoots per plant, fresh weight of tubers per plant and dry weight of tubers per plant were influenced with the increase in the per cent of RDF. Similar results were obtained by Baishya et al., (2013).

Nag et al., (2006) stated that the fresh weight of shoots/plant and dry weight of shoots/plant were found highest under the treatment in which crop residues and biofertilizers $($ Azotobacter + PSB) were incorporated. These results were found conformity with the results of Verma et al., (2011).

Table.1 Effect of INM on fresh and dry of leaves, stem and tubers in potato

\begin{tabular}{|c|c|c|c|c|c|c|c|c|}
\hline Treatments & $\begin{array}{l}\text { Fresh } \\
\text { weight } \\
\text { of } \\
\text { leaves } \\
\text { (g) }\end{array}$ & $\begin{array}{c}\text { Fresh } \\
\text { weight } \\
\text { of stem } \\
(\mathrm{g})\end{array}$ & $\begin{array}{c}\text { Fresh } \\
\text { weight } \\
\text { of tuber } \\
\text { (g) }\end{array}$ & $\begin{array}{c}\text { Dry } \\
\text { weight } \\
\text { of leaves } \\
\text { (g) }\end{array}$ & $\begin{array}{c}\text { Dry } \\
\text { weight } \\
\text { of stem } \\
\text { (g) }\end{array}$ & $\begin{array}{l}\text { Dry } \\
\text { weight } \\
\text { of } \\
\text { tuber } \\
\text { (g) }\end{array}$ & $\begin{array}{l}\text { Total } \\
\text { fresh } \\
\text { weight } \\
\text { of tuber } \\
\text { (g) }\end{array}$ & $\begin{array}{l}\text { Total } \\
\text { dry } \\
\text { weight } \\
\text { of tuber } \\
\text { (g) }\end{array}$ \\
\hline$T_{1}$ & 23.48 & 51.54 & 216.00 & 6.45 & 11.98 & 35.67 & 277.67 & 52.33 \\
\hline$T_{2}$ & 25.00 & 56.33 & 221.67 & 7.06 & 12.57 & 37.33 & 286.67 & 56.67 \\
\hline $\mathbf{T}_{3}$ & 27.00 & 57.67 & 235.00 & 7.33 & 13.49 & 38.67 & 302.85 & 61.00 \\
\hline $\mathbf{T}_{4}$ & 33.81 & 62.33 & 255.00 & 7.56 & 13.78 & 44.33 & 329.00 & 71.00 \\
\hline$T_{5}$ & 33.00 & 61.58 & 251.00 & 7.33 & 12.74 & 43.00 & 324.33 & 68.17 \\
\hline$\overline{T_{6}}$ & 32.50 & 1.68 & 251.33 & 7.40 & 11.70 & 42.83 & 324.33 & 68.17 \\
\hline $\mathbf{T}_{7}$ & 32.00 & 60.33 & 249.67 & 7.21 & 11.32 & 42.67 & 322.17 & 66.67 \\
\hline $\mathbf{T}_{8}$ & 32.60 & 61.78 & 250.33 & 7.18 & 11.63 & 42.17 & 323.33 & 66.33 \\
\hline$\overline{T_{9}}$ & 31.00 & 3 & 10 & 7.14 & 1 & 41.00 & 319.33 & 64.33 \\
\hline$T_{10}$ & 36.59 & 63.33 & 278.33 & 7.86 & 13.86 & 46.67 & 383.33 & 80.00 \\
\hline$\overline{T_{11}}$ & 44.37 & 71.18 & 292.33 & 9.33 & 17.60 & 54.33 & 415.00 & 93.67 \\
\hline$\overline{T_{12}}$ & 42.95 & 70.04 & 285.00 & 8.81 & 15.61 & 54.00 & 405.00 & 92.00 \\
\hline$T_{13}$ & 45.41 & 74.67 & 301.67 & 9.39 & 17.90 & 55.00 & 426.67 & 96.67 \\
\hline $\mathrm{T}_{14}$ & 43.01 & 71.00 & 291.67 & 8.87 & 16.53 & 54.17 & 412.33 & 93.00 \\
\hline S. E m \pm & 2.81 & 3.72 & 9.84 & 0.49 & 1.14 & 2.14 & 10.46 & 2.68 \\
\hline CD@5\% & 8.18 & 10.81 & 28.62 & 1.43 & 3.33 & 6.22 & 30.40 & 7.78 \\
\hline
\end{tabular}


Table.2 Effect of INM on tuber characteristics of potato

\begin{tabular}{|c|c|c|c|c|c|}
\hline Treatments & $\begin{array}{c}\text { Tuber } \\
\text { length }(\mathrm{cm})\end{array}$ & $\begin{array}{c}\text { Tuber } \\
\text { circumference } \\
(\mathbf{c m})\end{array}$ & $\begin{array}{c}\text { Tuber } \\
\text { shape }\end{array}$ & Tuber size & $\begin{array}{c}\text { Depth of } \\
\text { eyes }\end{array}$ \\
\hline $\mathrm{T}_{1}$ & 5.89 & 8.33 & Round & Small & Moderate \\
\hline $\mathrm{T}_{2}$ & 6.85 & 9.67 & Round & Medium & Moderate \\
\hline $\mathrm{T}_{3}$ & 6.86 & 10.03 & Round & Medium & Moderate \\
\hline $\mathrm{T}_{4}$ & 6.89 & 14.45 & Round & Medium & Moderate \\
\hline $\mathrm{T}_{5}$ & 6.79 & 14.22 & Round & Medium & Moderate \\
\hline $\mathrm{T}_{6}$ & 6.91 & 14.43 & Round & Medium & Moderate \\
\hline $\mathrm{T}_{7}$ & 6.82 & 14.16 & Round & Medium & Moderate \\
\hline $\mathrm{T}_{8}$ & 6.84 & 14.00 & Round & Medium & Moderate \\
\hline $\mathrm{T}_{9}$ & 6.81 & 13.59 & Round & Medium & Moderate \\
\hline $\mathrm{T}_{10}$ & 7.79 & 14.67 & Round & Big & Moderate \\
\hline $\mathrm{T}_{11}$ & 8.58 & 14.90 & Round & Big & Moderate \\
\hline $\mathrm{T}_{12}$ & 8.51 & 14.83 & Round & Big & Moderate \\
\hline $\mathrm{T}_{13}$ & 8.79 & 15.00 & Round & Big & Moderate \\
\hline $\mathrm{T}_{14}$ & 8.55 & 14.88 & Round & Big & Moderate \\
\hline $\mathrm{S}_{\mathbf{E}} \mathrm{E} \pm$ & 0.44 & 0.86 & - & - & - \\
\hline $\mathrm{CD} @ 5 \%$ & 1.28 & 2.51 & - & - & - \\
\hline
\end{tabular}

Fig.1 Effect of INM on leaf area index in potato

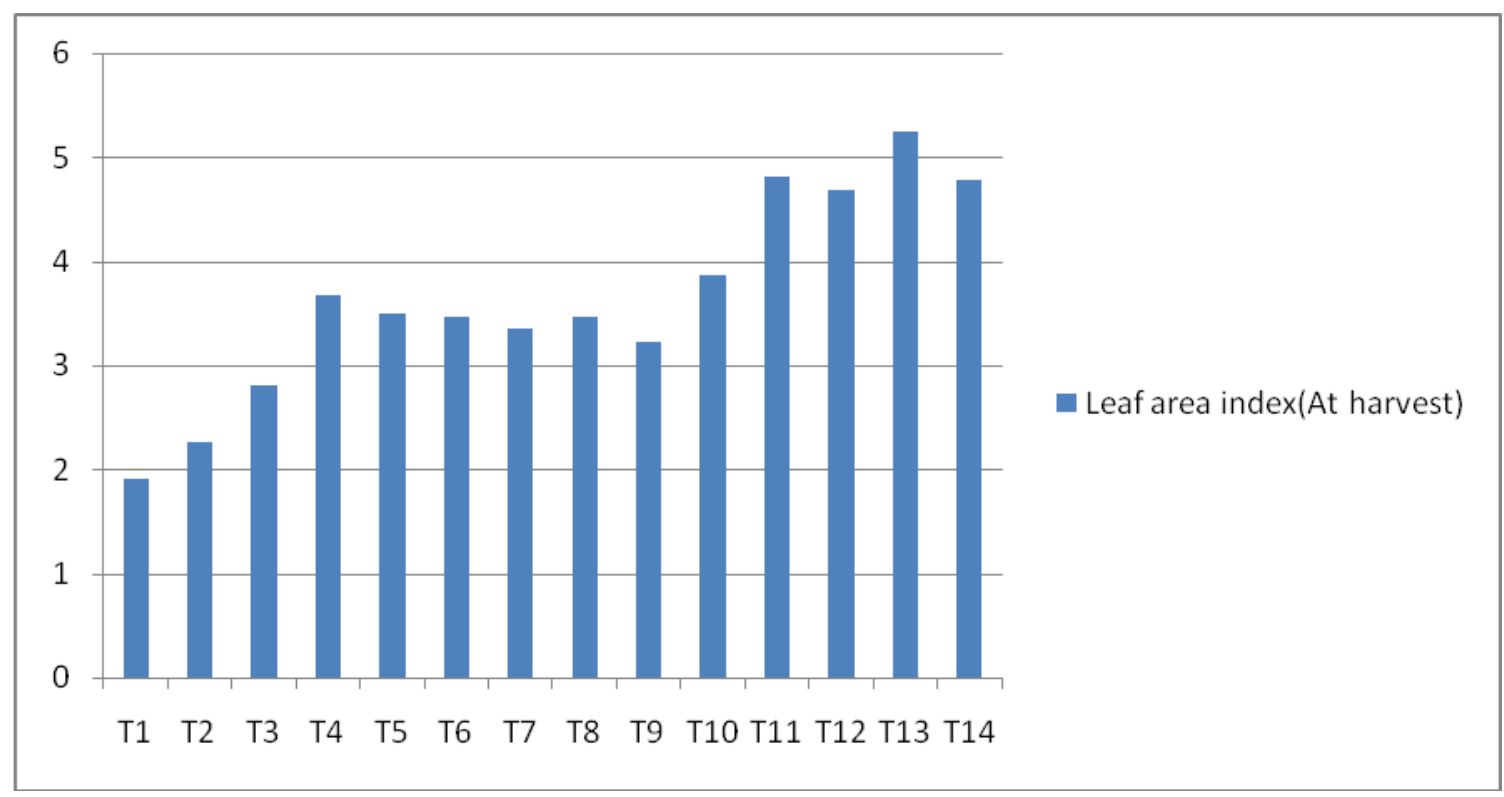


Plate.1 Best performing treatments

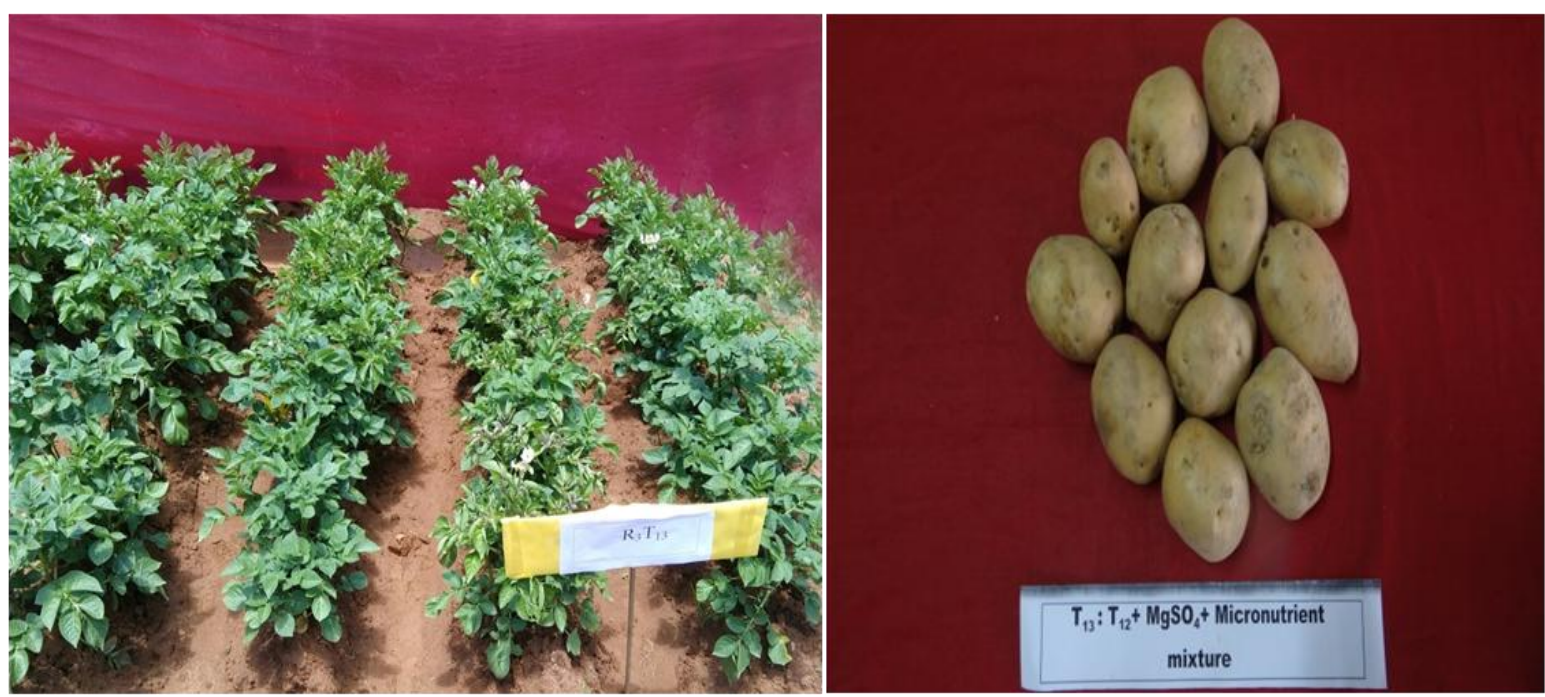

$\mathrm{T}_{13}-75 \% \mathrm{RDF}+$ Azotobacter $+\mathrm{PSB}+\mathrm{KSB}+\mathrm{MgSO}_{4}+$ Micronutrient mixture

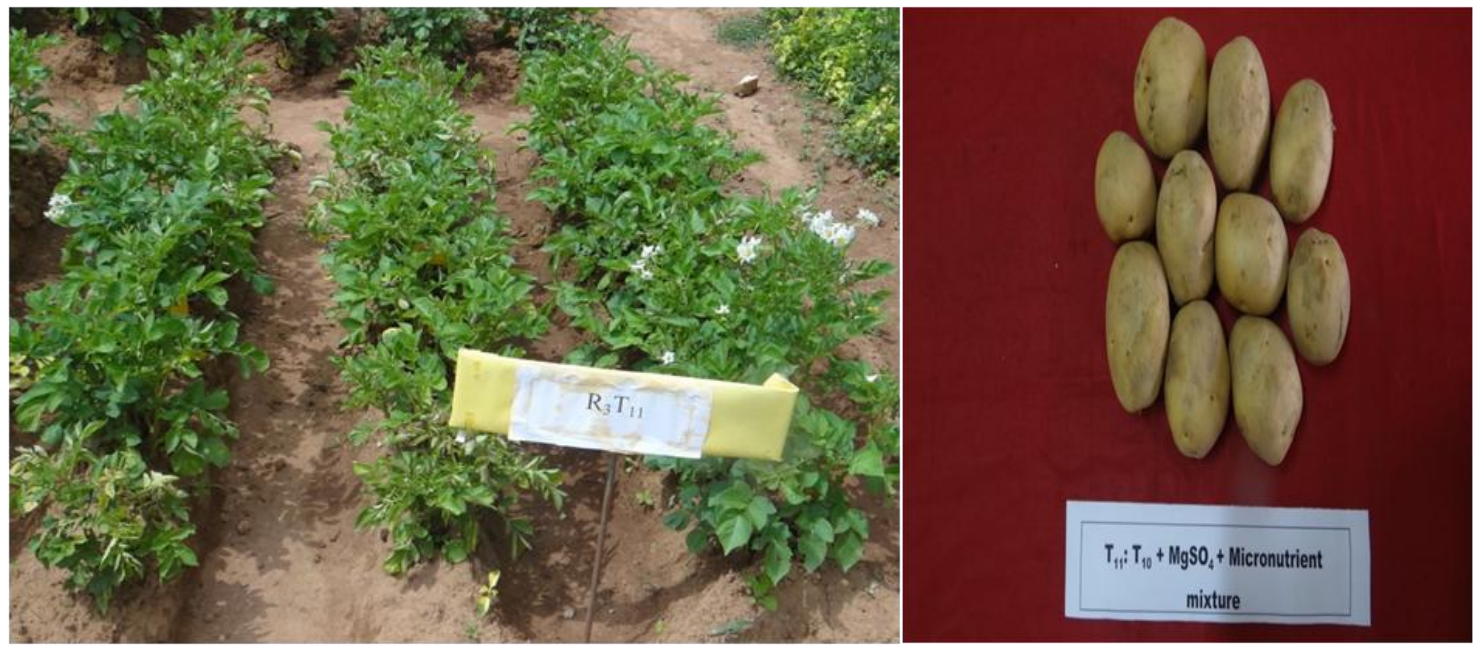

$\mathrm{T}_{11}-50 \% \mathrm{RDF}+\mathrm{VC}+$ Azotobacter $+\mathrm{PSB}+\mathrm{KSB}+\mathrm{MgSO}_{4}+$ Micronutrient mixture

The tuber length and tuber circumference varied significantly as influenced by different integrated nutrient management (Table 2) practices. Plants which were fertilized with Azotobacter $+\mathrm{PSB}+\mathrm{KSB}+\mathrm{MgSO}_{4}+$ Micro nutrient mixture $+75 \% \mathrm{RDF}\left(\mathrm{T}_{13}\right)$ recorded the maximum tuber length $(8.79 \mathrm{~cm})$ and tuber circumference $(15 \mathrm{~cm})$. Increased tuber length and circumference in these treatments could be related to increased plant height, number of stems/plant and number of leaves/plant which were positively contributed towards tuber length. Increased tuber length and circumference are because of balanced nutrition and better uptake of nutrients by the plants which helped for better tuberization and the interaction effect bio-fertilizers with NPK and FYM enhanced the synthesis of photosynthates by increasing the synthesis of growth regulators, amino acids and vitamins. High tuber length and circumference of potato plant ultimately resulted in more tuber yield per hectare. These results were in conformity with the findings of Keisham et al., (2015) who 
reported that in potato that the supplementation of $75 \%$ RD of nitrogen from Urea, i.e., 130 $\mathrm{kg} / \mathrm{ha}$ and $25 \% \mathrm{RD}$ of nitrogen increased the yield attributes and yield of potato.

Tuber shape, size and depth of the eyes were not much influenced due to integrated nutrient management practices (Table 2). All the tubers were of moderate depth and medium bigger in size. Gobana (2002) stated that majority of genotypes were found to be shallow eyed followed by the medium depth and were round shape.

\section{Acknowledgement}

Central Potato Research Institute, Shimla, Himachal Pradesh

Central Potato Research Station, Modipuram for supplying seed tubers.

\section{References}

Anonymous, 2015. www.nhb.gov.in. National Horticulture Board, Statistical data.

Baishya, L. K., Gupta, V. K., Lal, S. S., Das, B. $\mathrm{K}$ and Kumar, M., 2013. Effect of biofertilizers on growth and yield of potato in north eastern hills of India. Potato J., 32: 3-4.

Chopra, S., Kanwar, J. S and Samnotra, R. K., 2006. Effect of different levels of nitrogen and potassium on growth, yield and biochemical composition of potatoes variety Kufri Jawahar. Envi. and Ecol., 24(2): 268-271.

Gobana, D. R., 2002. Genetic variability, heritability and path coefficient studies in potato (Solanum tuberosum L.). M.Sc
(Hort.) thesis, Univ. Agric. Sci., Dharwad, Karnataka (India). p. 166.

Jagadeesh, K. S., Geeta, G. S and Suvarna, C. V., 1994. The effect of biogas spent slurry in combination with chemical $\mathrm{N}$ fertilizer on pod yield of chilli (Capsicum annuum L.). South Indian Hort., 42(2): 96-101.

Keisham, A., Heisnam, P., Moirangthem, A., Das, T., Indrakumar, N., Singh and Singh, L. N., 2015. Effect on growth and yield of potato (Solanum tuberosum) var. Kufri Jyothi by nitrogen integration with different organic sources and its after effect on soil. The bioscan, 10(3): 13351338.

Khurana, P. S. M and Naik, P. S., 2003. The Potato: an overview. In: the Potato Production and Utilization in Sub-tropics (Edited by S. M. Paul Khurana, J. S. Minas and S. K. Pandey) Mehta Publication, New Delhi, 1-14.

Nag, G. P., 2006. Integrated nutrient management in potato for Chhattisgarh plains. M. Sc. (Ag) Thesis IGKV, Raipur. pp. 94-95.

Sestak, Z., Catasky, J and Jarvis, P. G., 1971. Plant photosynthetic production; manual of methods. (Ed. Junk N.V.), The Haque Publishers, pp. 72-78.

Verma, S. K., Asati, B. S., Tamrakar, C. K., Nanda, H. C and Gupta, C. R., 2011. Effect of organic components on growth, yield and economic returns in potato, Potato J., 38(1): 51-55.

Yadu, D., 2011. Effect of varying levels of NPK fertilizers and size of seed tubers on growth and yield of potato (Solanum tuberosum L.) in Alfisol. M. Sc. (Ag.) IGKVV Raipur.

\section{How to cite this article:}

Shubha, A.S., V. Srinivasa, A. Shanwaz, R.B. Anusha and Sharavathi, M.B. 2018. Effect of Integrated Nutrient Management on Growth and Yield Attributes in Potato (Solanum tuberosum L.). Int.J.Curr.Microbiol.App.Sci. 7(09): 830-836. doi: https://doi.org/10.20546/ijcmas.2018.709.099 